\title{
Power Generation Using Fuel Cell in the Application of Sensor Power Supply
}

\author{
Sabha Raj Arya, Nunsavath Sharath Kumar \\ and B. R. Ananthapadmanabha \\ Department of Electrical Engineering, \\ Sardar Vallabhbhai National Institute of Technology, \\ Surat-395007, Gujarat, India \\ E-mail: sabharaj79@gmail.com; mean.machine3011@gmail.com; \\ and ananthpbr@gmail.com
}

Received 15 April 2017; Accepted 27 July 2017;

Publication 22 August 2017

\begin{abstract}
Due to the growing demand for energy sets concern for the researchers to emphasize power generation through non-conventional sources because of their advantages over conventional source. This leads towards the intense research work carried out on fuel cells. Fuel cells have the ability of supplying electricity in the situation where the scope of conventional or other non-conventional power generating option is difficult to implement. The other advantages are transportability, flexibility, suitability and environment friendly operation. The particular advantage of transportability is well utilized in distributed power applications such as on board power supplies. This paper focuses on a low power converter energized by a fuel cell. It gives an overview of modelling of fuel cell and flyback converter with its different topologies that can be used in sensor application. Here different topologies of flyback converter are taken into consideration and out of these different topologies, the highest efficiency topology is chosen to supply power to the sensors and thereby its performance is tested. This converter is compared with the conventional method of supplying power to the sensor board and their performance is observed in terms of efficiency and other parameters. The simulation results are discussed and the performance is validated through experimental results.
\end{abstract}

Journal of Green Engineering, Vol. 7, 159-188.

doi: 10.13052/jge1904-4720.7128

(c) 2017 River Publishers. All rights reserved. 
Keywords: Fuel cell, Flyback converter, Active clamp, Sensor, RCD snubber, Interleave, Two switch.

\section{Introduction}

The growth in industrialization and population lead to increase in energy demand and to meet this ever increasing demand of energy, power generation companies and also individuals are inclined to opt for cheaper, cleaner and safer energy alternatives such as solar photovoltaic (PV), wind energy, tidal energy, fuel cell and so on [1]. Fuel cell has a great potential to be a green power source due to its high efficiency, flexible modular structure and zero or low emission of pollutant gases. Proton exchange membrane fuel cell (PEM-FC) is the most convenient fuel cell system (FCS) for embedded applications because of its low pressure and operating temperature [2]. Traditional fossil fuel resources are depleting quickly, their continued use contributes to increasing pollution [3]. Development of clean energy systems is essential. With regard to fuel cell, it can be considered as one of the most essential method of clean-energy [4]. With increase in energy demand and rise in energy crisis have led to continuous research on non-conventional power generation and its power conditioning systems [5]. Fuel Cell System (FCS) has risen to be more environmental friendly and efficient due to its low emissions and high energy conversion efficiency [6].

Fuel cell is one of the best choices among the other traditional energy sources due to its capability of operating at higher efficiency with no adverse effect on environment [7]. It is observed that the research on fuel cell based power generation has drastically increased in recent times. Fuel cell is basically an electrochemical device that converts chemical energy into electrical energy i.e. it almost acts as a battery as long as the fuel (Hydrogen and oxygen) are supplied to it giving water and heat as residues [8]. The fuel cell is largely endorsed by many countries to be used in electric motorcycles, cell phone batteries, electric vehicles, small-scale power stations etc. [9]. A fuel cell with its inherent low terminal voltage is recognized as one of the clean energy systems for the industries and residential utilization to reduce the pollution [10]. Problems about energy crisis and environment pollution related to fossil fuel is intensively studied all over the world. Energy saving and looking for new-generation reproductive energy source are considered helpful for attenuating these problems [11]. Moreover, the fuel cell (FC) is ecofriendly because only water and heat are produced as by-products [12]. Among various types of FC, the PEMFC is suitable for some special applications 
such as unmanned aerial vehicles (UAVs) because of ease of miniaturization [13]. Proton exchange membrane fuel cell (PEMFC) is suitable for small scale power generation which works at a low temperature in the range of $60^{\circ} \mathrm{C}-100^{\circ} \mathrm{C}[14]$.

Due to drastic increase in usage of electric drives, there is requirement to develop power supply in addition to meeting the demand for higher efficiency and higher power density [15]. Confronting these demand will require thermal considerations, proper selection of discrete components, efficient design, optimal topology etc. [16]. In this literature, steps to develop a power circuit for a sensor card is discussed. A $90 \mathrm{~W}$ flyback converter is designed providing a dc output of $\pm 15 \mathrm{~V}$ at $6 \mathrm{~A}$ with switching frequency of $5 \mathrm{kHz}$ as the drive application requires sensing the power supply for sensor need to be efficient with higher power density [17]. Fuel cell can be used to supply power to sensors such as level sensor, angle sensor, anemometer sensor, motion sensor, pressure sensor, temperature sensor, wind vane sensor etc. which could be supplied by isolated dc-dc converter.

The switching frequency of these converters is normally in the range of $\mathrm{kHz}$ which reduces the transformer size. Nowadays, A SMPS has become an inevitable source to power the low power converter in which flyback topology is mainly used which gives the isolation feature in low power applications [18, 19]. Generally flyback converters are popular for their easy design and simplicity with low cost which can be used to power a low power application upto $200 \mathrm{~W}$. Flyback converter are basically derived from buck boost converter and they are extensively used in industries [20]. But when it comes to reliable and safe operation necessary steps must be taken to absorb the energy from leakage inductance and to reduce voltage spikes using the clamp circuit [21]. For the purpose of clamping, different topologies of flyback converter are available namely active clamped converter, RCD snubber converter, interleaved converter and two switch converter. Commonly in clamp circuits, passive clamp circuits are largely used as it does not require drive or control circuit [22]. RCD clamp circuit is generally used to suppress the voltage spikes efficiently [23]. In two switch flyback converter by using two switches the voltage stress across the switch can be limited to the extent that voltage stress is reduced to input voltage thereby reducing the conduction and switching losses and lets the implementation of control logic simple and easy. In this situation the design of flyback isolated transformer becomes a challenging task when required to store large energy [24]. By interleaving the flyback converter, converter can be designed for high power application and by increasing the interleaving cells frequency of harmonics increases which reduces the filter requirement. 
In this paper a fuel cell is used instead of the conventional power generator to produce the power in direct current (DC) and is fed to different flyback converter topologies and the highest efficiency producing converter is chosen for powering the sensor for sensor applications. As such simulation is performed on different topologies and implemented. Isolated transformer of flyback converter is considered to be center tapped producing +ve (positive) voltage. It is required by the sensor card. Here when compared with conventional linear regulators which are used having very low efficiency, flyback converter gives far better performance and efficiency. Due to this reason the flyback converter is the best choice to power the sensor, so the flyback converter of mentioned specification with highest efficiency is selected in this paper to power the sensor.

\section{System Configuration}

System considered here is a power supply system to the sensor using fuel cell as the power generating entity of dc supply. Fuel cell is basically electrochemical device which converts the chemical energy into electrical energy using fuel i.e. hydrogen and oxygen which are fed to fuel cell to produce electrical energy. As hydrogen is not readily available, a fuel reformer is used to extract hydrogen rich gas from hydrogen compound like water or fossil fuels. Then this hydrogen and oxygen gases are fed into the fuel stack where number of fuel cell are connected in series to produce higher voltage and this method is called stacking. After the chemical reaction the by-product left is water and heat in this process. The Detailed parameter of fuel cell and flyback converter is given in Appendix-A.

The basic block diagram of fuel cell based sensor power supply using flyback converter is shown in Figure 1. So the generated dc output is then fed to flyback converter. Flyback converter is a dc-dc isolated converter with added advantages of isolation and provides multiple outputs which can be utilized to power up the sensors those require dual voltages. Flyback converters of different topologies is used with gating pulses of variable duty cycle thereby controlling the output voltage. The output of the flyback converter is sensed and is compared with the reference i.e. the error signal is generated which is fed to the PI controller as shown in Figure 2 which generates the required duty cycle by comparing signal with saw tooth wave to minimize the error signal and to give the desired output that can be fed to the load. Here efficiency as the main concern is taken into account and higher efficiency flyback converter is chosen to feed this power to any sensor as per the requirement. 


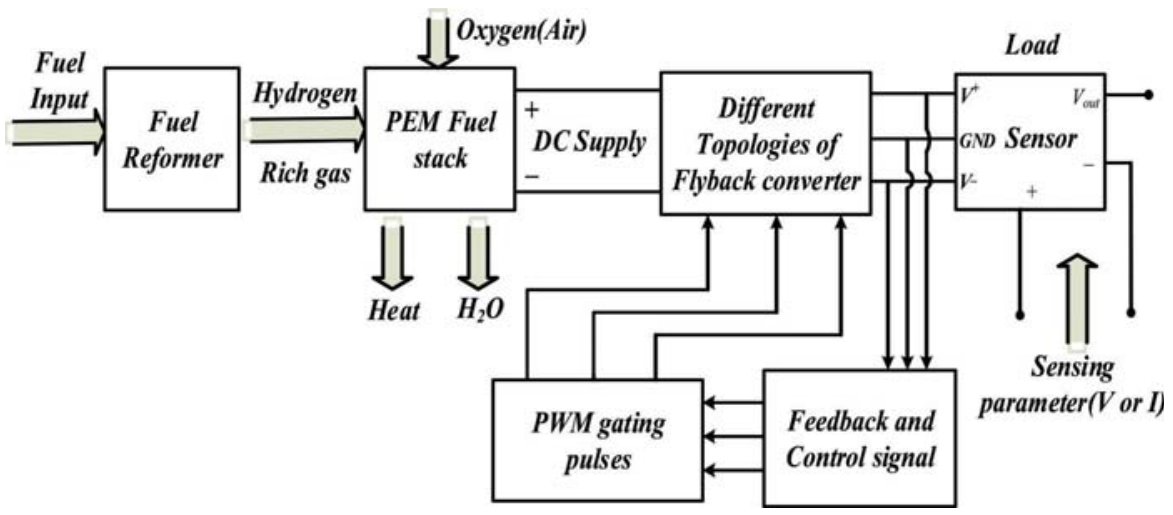

Figure 1 Block diagram of fuel cell based sensor power supply using flyback converter.

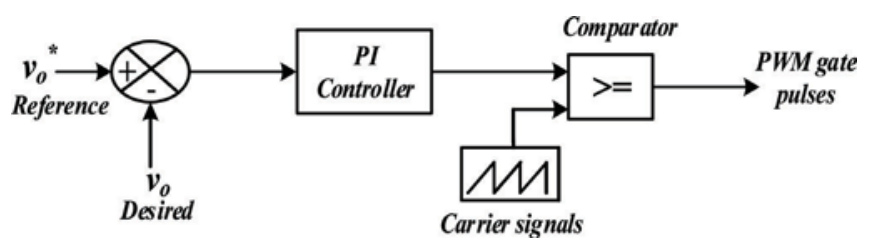

Figure 2 Block diagram of feedback and control signal to produce gate pulses.

\subsection{Fuel Cell}

Fuel cell is an electrochemical device which converts the chemical energy i.e. fuel (hydrogen and oxygen) directly into electrical energy. However, in fuel cell the oxidant and reductant are to be fed continuously for uninterrupted operations unlike batteries. Electrolyser's features are important places in a fuel cell. Although the fuel cells can process a broad variety of oxidants and fuels, the main interest is on the easily available and commonly used fuel derived from fossil fuel. A simple general model for the fuel cell that could help understand the function of the fuel cell is developed and implemented. The fuel cell basically consists of an anode and a cathode on either sides with electrolyte layer and the basic construction or building block as shown in the Figure 3.

An unit cell of fuel cell is represented with the product/reactant gases and direction of flow of the ion as shown in Figure 3. Typical fuel cell has its fuel fed constantly to the positive electrode (anode) and oxygen (oxidant) is fed to the negative electrode (cathode). The electricity is produced at the electrodes due to the electrochemical reactions through electrolyte which feeds the load. Classification of fuel cell is done based on the type of electrode used 


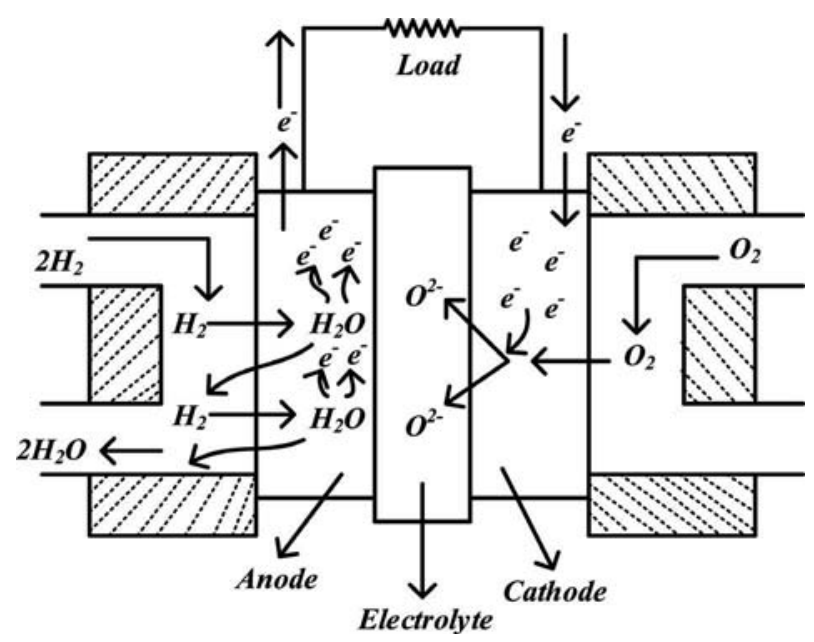

Figure 3 Basic Fuel Cell Components.

which determines the type of ions carried and electrode reactions across the electrolyte. Mostly today the fuel cells uses hydrogen gas as fuel due to its high reactivity property for anode reactions. Similarly oxygen which is a widely and readily available gas is used as oxidant. In places where not enough space is available both oxygen and hydrogen can be stored in cryogenic form compactly with water as the reaction product. In practical scenario fuel cell units need to be stacked to achieve power and voltages of required level for that required application. Stacking is nothing but connecting multiple fuel cell units in series.

The operation of the fuel cell is best described by the half-cell reactions at the anode and cathode electrodes. The role of electrodes and electrolyte are enabling this reaction. At the anode, hydrogen dissociates at the catalyst producing $\mathrm{H}^{+}$ions and electrons. The half-cell reaction is shown in Equation (1).

$$
2 \mathrm{H}_{2} \Rightarrow 2 \mathrm{H}^{+}+2 e^{-}
$$

The cathode half-cell reaction is shown in Equation (2).

$$
\frac{1}{2} \mathrm{O}_{2}+2 e^{-}+2 \mathrm{H}^{+} \Rightarrow \mathrm{H}_{2} \mathrm{O}
$$

The change in gibbs free energy is an energy produced in a chemical reaction. The work done in this process is same as the change in the Gibbs free energy of formation. That is, mathematically expressed in Equation (3). 


$$
\Delta g_{f}=-2 D e E=-(2 C E)
$$

Where ' $\Delta \mathrm{g}_{\mathrm{f}}$ ' is the change in the Gibbs free energy, ' $\mathrm{E}$ ' is the EMF of the PEM fuel cell, ' $\mathrm{D}$ ' is Avogadro's number (the number of molecules in one mole), ' $\mathrm{C}$ ' is Faraday's constant and ' $\mathrm{e}$ ' the charge of the electron. So the open circuit voltage of the fuel cell is given by Equation (4).

$$
E^{0}=\frac{\Delta g_{f}}{2 C}
$$

The Nernst equation gives the relationship between actual voltage produced at different pressures and temperatures of the products and reactants and standard potential for a cell reaction which is given in Equation (5).

\subsubsection{Nernst equation}

Nernst equation is normally used to find the concentration of one of the components of electrochemical cell and to compute the voltage of an electrochemical cell. In normal conditions, cell potentials are calculated with the temperature and pressure maintained at standard pressure and temperature with same concentration of solution. But unlike it, Nernst equation is used to compute cell potentials in non-standard conditions. It transforms the standard cell potential formula by taking the temperature and concentrations of the reaction component into account. This Nernst equation is denoted by Equation (5). The relation effected by change in the temperature and the membrane or electrolyte used.

$$
E=E^{0}+\frac{U T}{2 C} \ln \frac{P_{\text {reactant }}}{P_{\text {product }}}
$$

Where ' $\mathrm{P}_{\text {reactant }}$ ' is the product of partial pressures of the reactants and ' $\mathrm{P}_{\text {product }}$ ' is the product of the partial pressures of the products produced in the cell reaction. All pressures are expressed in bars. ' $C$ ' is the Faraday's constant, ' $\mathrm{U}$ ' is the universal gas constant and ' $\mathrm{T}$ ' is the operating temperature of the fuel cell.

There are a number of causes for the difference in the actual voltage and the ideal reversible open circuit voltage in the fuel cell due to polarization, irreversibility and losses because of resistance, activation losses, internal currents, fuel crossover, ohmic losses and mass transportation losses. Final output voltage is mentioned in Equation (6).

$$
V=E^{0}+\frac{3 U T}{4 C} \ln \frac{P_{2}}{P_{1}}-\left(i+i_{n}\right) * R-A \ln \frac{\left(i+i_{n}\right)}{i_{0}}+B \ln \left(1-\frac{i+i_{n}}{i_{l}}\right)
$$


In this equation, ' $\mathrm{E}^{0}$ ' is the open circuit voltage, ' $\mathrm{R}$ ' is the specific resistance, ' $i_{n}$ ' is the internal current density ' $i_{0}$ ' is the exchange current density, ' $A$ ' is the slope of Tafel curve, ' $\mathrm{B}$ ' is mass transfer over voltage constant and ' $\mathrm{l}_{1}$ ' is the limiting current density at the electrode. Typical values for a PEM fuel cell constants are given in the Table 1 [3].

\subsection{Basic Flyback Converter and Its Different Topologies}

The flyback converter is basically derived from the buck-boost converter. Here, the inductor of the buck-boost converter is replaced by the transformer normally called as two winding inductor or flyback transformer. Here the current in both the winding does not flow simultaneously unlike in the case of normal transformer. The magnetizing inductance plays the role of inductor and it is switched between the primary and secondary winding. When the switch ' $\mathrm{S}$ ' turns on, diode (D) is reverse-biased. The primary winding does the duty of an inductor connected to the input fuel cell voltage $\left(\mathrm{V}_{\mathrm{FC}}\right)$. This flyback transformer stores the energy in the form of magnetic field. When the switch turned off, no current flows in the primary winding. Now the diode (D) gets forward biased due to the magnetizing current, referred to the secondary winding. Then the flyback transformer transfers the stored energy in magnetic field to the out put. The flyback converter topology is shown in Figure 4. In small and medium power applications, generally these flyback converters are used. Single ended flyback converter is the simplest form of all isolated converters. The flyback converter can operate in either the continuous mode or the discontinuous mode. By applying the volt-second balance equation, the continuous conduction mode is discussed below. The DC input and output relations are given as,

$$
\mathrm{V}_{\text {out }}=\mathrm{n} * \mathrm{~V}_{\text {in }} *(\mathrm{D} / 1-\mathrm{D})
$$

Where $\mathrm{D}=$ Duty ratio and $\mathrm{n}=$ Turns ratio

Table 1 Typical Values of Fuel Cell

\begin{tabular}{lc}
\hline Constant & Typical Value \\
\hline$E$ & $100 \mathrm{~V}$ \\
\hline$i_{n}$ & $2 \mathrm{mA.cm}$ \\
\hline$r$ & $0.03 \Omega . \mathrm{cm}^{2}$ \\
\hline$i_{0}$ & $0.067 \mathrm{mA.cm}$ \\
\hline$A$ & $0.06 \mathrm{~V}$ \\
\hline$B$ & $0.05 \mathrm{~V}^{-2}$ \\
\hline$i_{l}$ & $900 \mathrm{mA.cm}$ \\
\hline
\end{tabular}




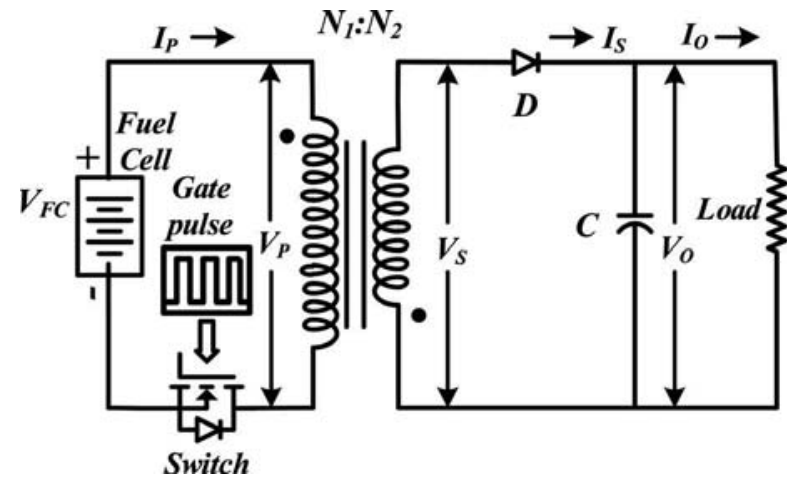

Figure 4 Basic circuit of flyback Converter.

It can be seen from Equation (7) that the conversion ratio is same as the buck-boost converter with $\mathrm{n}$ as an extra factor. Traditionally these converters are found in TV's and computer monitors with applications in the power range of 50-100 W. The Flyback converter has advantages of multiple outputs with minimal requirement of part count but has poor cross regulation. Figure 5 shows the performance waveform results of basic flyback converter with its various parameter representations. As it can be observed in Figure 5 that the voltage spikes in primary voltage $\left(\mathrm{v}_{\mathrm{P}}\right)$ and the current spikes in primary current $\left(I_{P}\right)$ is due to reverse recovery current from secondary side of transformer. Voltage across switch $\left(\mathrm{v}_{\mathrm{SW}}\right)$ in the waveform shows the voltage spikes across drain and source. Similarly spikes with oscillations can be observed in the secondary voltage $\left(v_{S}\right)$. There is a linear decrease in secondary current $\left(I_{S}\right)$ while the switch is turned off by maintaining the constant output voltage $\left(\mathrm{v}_{\mathrm{O}}\right)$ and output current $\left(\mathrm{I}_{\mathrm{O}}\right)$ for the given input voltage $\left(\mathrm{v}_{\mathrm{FS}}\right)$ from fuel cell as illustrated in the Figure 5.

Likewise the other topologies of flyback converter are also depicted in the similar way with an additional parameter consideration and they are shown as well as discussed individually in the forthcoming simulated waveforms.

\subsubsection{Different flyback converter toplogies}

The basic topology of a flyback converter circuit is shown in Figure 4. During the MOSFET switching process, the MOSFET experiences higher voltage stress which leads to reduced efficiency, electromagnetic interference and discontinuous conduction mode of operation issues. The voltage stress can be reduced with increased efficiency using suitable flyback converter topology. So, different flyback converter topologies are used as discussed below. 


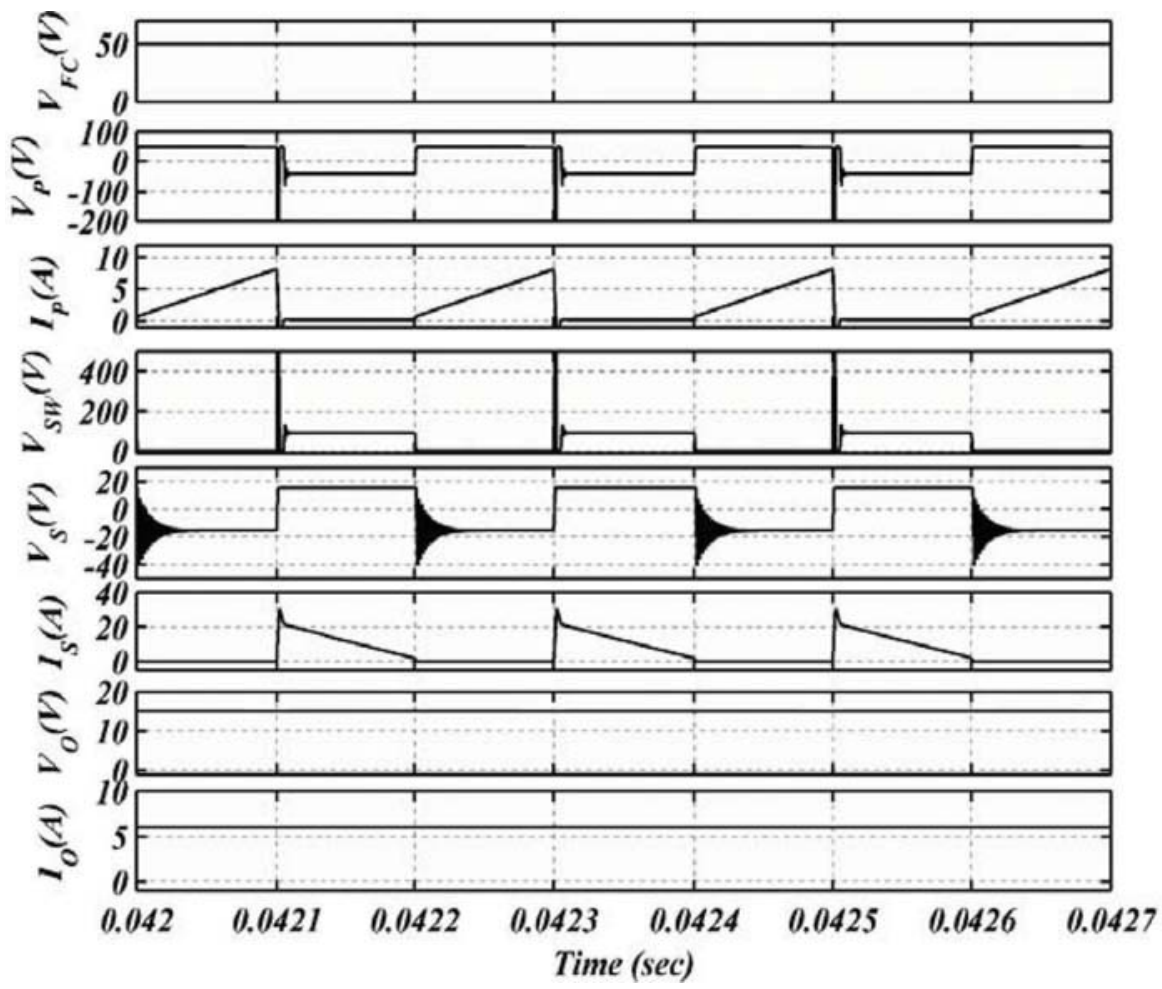

Figure 5 Performance waveforms of basic flyback converter with the fuel cell generated voltage as input voltage with a switching frequency of $5 \mathrm{kHz}$ at $50 \%$ duty cycle and graphs are as follows: fuel cell voltage $\left(\mathrm{v}_{\mathrm{FC}}\right)$, primary voltage $\left(\mathrm{v}_{\mathrm{P}}\right)$, primary current $\left(\mathrm{I}_{\mathrm{P}}\right)$, voltage across switch $\left(v_{S W}\right)$, secondary voltage $\left(v_{S}\right)$, secondary current $\left(I_{S}\right)$, output voltage $\left(v_{o}\right)$ and output current $\left(\mathrm{I}_{\mathrm{o}}\right)$ respectively.

\subsubsection{Active clamp flyback converter}

This topology consists of two MOSFET switches (Auxillary switch and main switch), transformer, clamp capacitor $\left(\mathrm{C}_{\text {clamp }}\right)$, and a diode (D). The clamp capacitor and the auxillary MOSFET switch makes the active clamp circuit. Due to the introduction of this clamping circuit the secondary current waveform of transformer will be affected. Here the leakage energy is shared between auxiliary MOSFET and main MOSFET which reduces the voltage stress on main MOSFET to eliminate discontinuous mode of operation. Using the active clamp circuit main MOSFET leads to zero voltage switching which reduces the switching losses. But here with introducing auxiliary MOSFET circuit complexity increases for gate driving control and current 


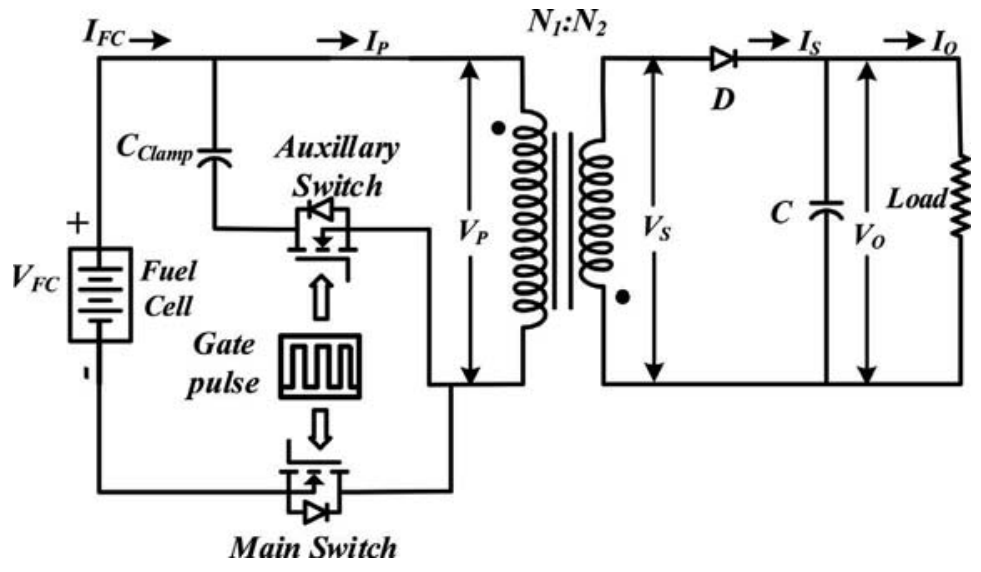

Figure 6 Basic circuit of active clamp flyback Converter.

stress increases. The active-clamp flyback converter configuration is shown in Figure 6. Figure 7 shows the simulated waveform results of basic active clamped flyback converter with its various parameter representations.

\subsubsection{Flyback converter with RCD snubber}

The circuit diagram of flyback converter with RCD snubber is shown in Figure 8. In this converter, when the voltage across MOSFET switch surpasses the reflected voltage of transformer and the input voltage then the snubber diode $\left(\mathrm{D}_{\mathrm{SN}}\right)$ is turned on which leads to leakage inductor current absorption and voltage clamping. Large valued snubber capacitor must be chosen such that its voltage remains constant during the switching period. Here snubber resistor $\left(\mathrm{R}_{\mathrm{SN}}\right)$ is used to dissipate the energy which is carried by the capacitor in every cycle. By operating the flyback snubber separately the voltage across the clamp capacitor $\left(\mathrm{C}_{\mathrm{SN}}\right)$ can be regulated.

Figure 9 shows the simulated waveform results of basic RCD snubber flyback converter with its various parameter representations.

\subsubsection{Interleaved flyback converter}

The circuit diagram of interleaved flyback converter is shown in Figure 10 interleaved flyback converters consist of two switches namely switch $\mathrm{SW}_{1}$ and switch $\mathrm{SW}_{2}$ which are turned on at alternate half cycles and whose secondary currents are summed through two rectifying diodes $\mathrm{D}_{1}$ and $\mathrm{D}_{2}$. The dc flux here is shared equally in these two primary winding which in turn reduces the copper and the core losses. 


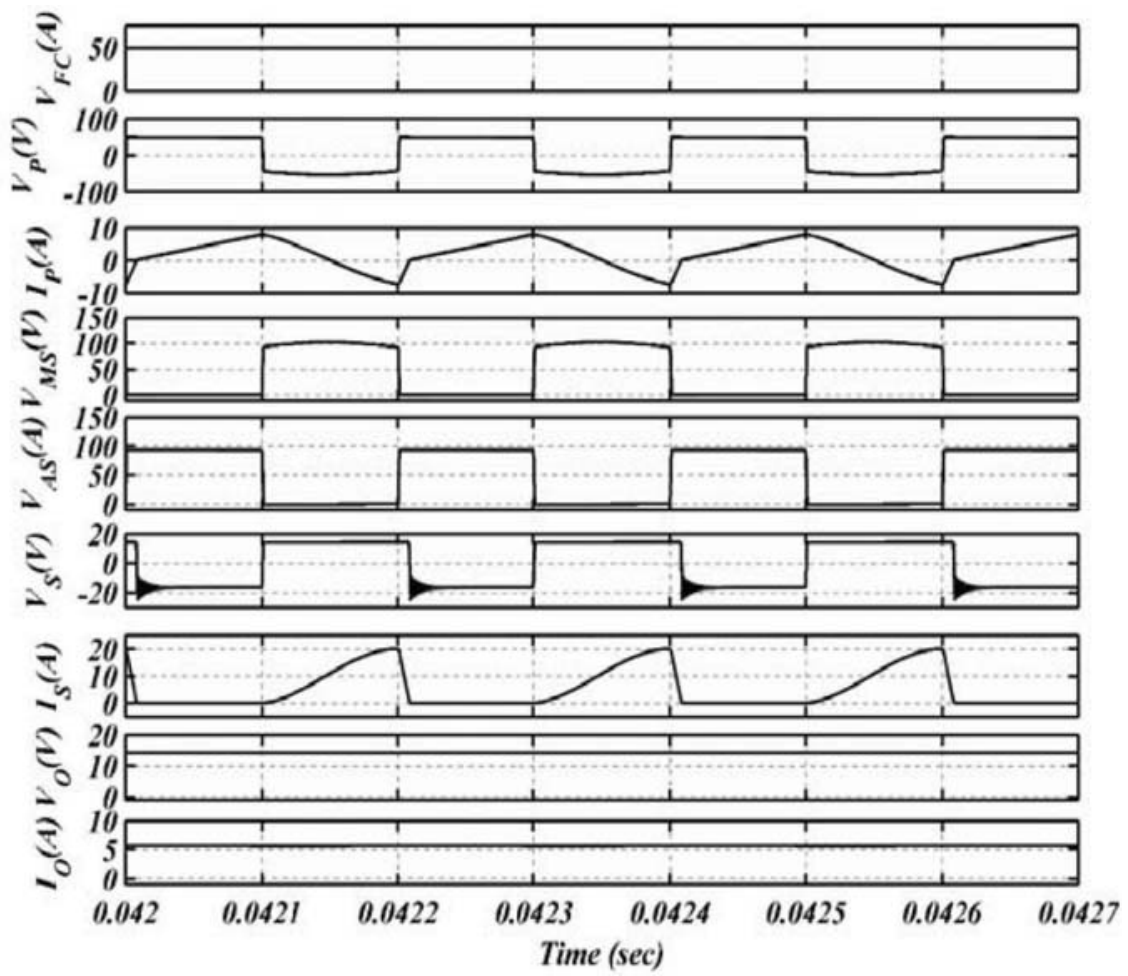

Figure 7 Performance waveforms of active clamp flyback converter with fuel cell generated voltage as input voltage with a switching frequency of $5 \mathrm{kHz}$ at $50 \%$ duty cycle. Graph parameters are plotted as follows fuel cell voltage $\left(v_{F S}\right)$, Primary voltage $\left(v_{P}\right)$, primary current $\left(\mathrm{I}_{\mathrm{P}}\right)$, voltage across the main switches $\left(\mathrm{v}_{\mathrm{MS}}\right)$ and the auxiliary switch $\left(\mathrm{v}_{\mathrm{AS}}\right)$, secondary voltage $\left(\mathrm{v}_{\mathrm{S}}\right)$, secondary current $\left(\mathrm{I}_{\mathrm{S}}\right)$ with output voltage $\left(\mathrm{v}_{\mathrm{o}}\right)$ and output current $\left(\mathrm{I}_{\mathrm{o}}\right)$ respectively.

Total load current is balanced at its secondary of the two transformers which reduces the diode rectification losses. Each MOSFET switch at its input acts as the auxiliary switch for each other, so that both the switches can achieve zero voltage switching operation. Figure 11 shows the simulated waveform results of basic interleaved flyback converter with its various parameter representations.

\subsubsection{Two switch flyback converter}

Basic operation of the two-switch flyback converter power stage is similar to the traditional flyback topology. In the beginning of the switching period, both MOSFET switches $\mathrm{Q}_{1}$ and $\mathrm{Q}_{2}$ are closed and the primary of the transformer is 


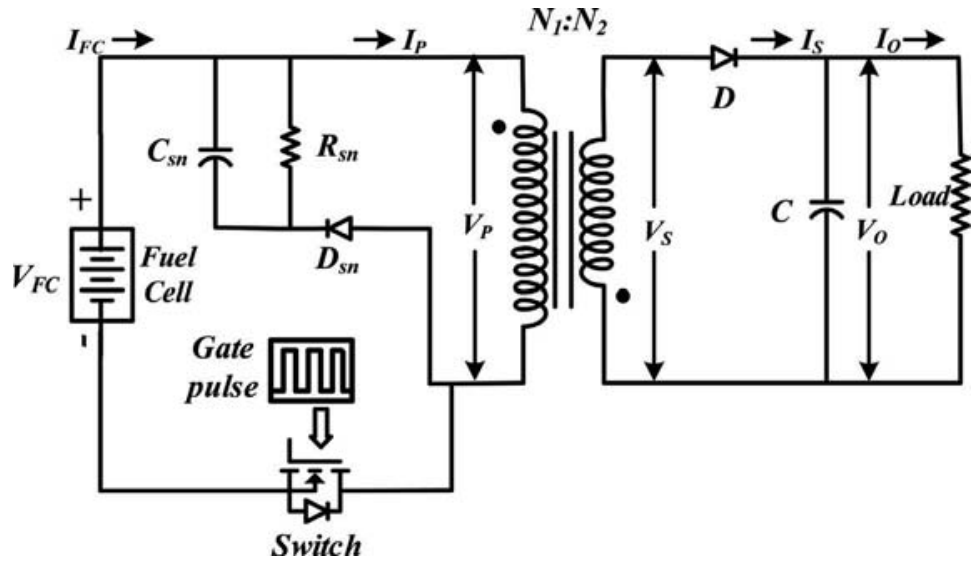

Figure 8 Basic circuit of RCD snubber flyback Converter.

connected between the input voltage and the ground. Current $\left(\mathrm{I}_{\mathrm{P}}\right)$ starts to flow through the primary, and the diode (D) on the secondary side is reverse biased due to the transformer polarity. Therefore, all the energy is stored in the coupled inductor while the load current $\left(\mathrm{I}_{\mathrm{O}}\right)$ is supplied by the output capacitor. The time frame during which the switches are closed is called the magnetizing period. When the switches are opened, stored energy is transferred to the output, supplying the load and the charging output capacitor (C). At the same time, the reflected voltage is applied across the primary. The time frame during which the switches are open is called the demagnetizing period. The circuit diagram of two switch flyback converters is shown in Figure 12. Generally basic flyback converter is commonly used in very low power applications whereas two switch topology can be used for high power applications. The diodes $\mathrm{D}_{1}$ and $\mathrm{D}_{2}$ are used to reduce the stress on switches to input voltage. Here the two MOSFET switches share the voltage stress produced due to leakage inductance. Recovering of leakage energy back to input is done by clamping the diodes $\mathrm{D}_{1}$ and $\mathrm{D}_{2}$.

Figure 13 shows the simulated waveform results of two switch flyback converter with its various parameter representations.

Figure 14 shows the voltage stress on the MOSFET switch in different flyback converter topologies when compared with the conventional flyback converter. As it can be observed from Figure 9 that a conventional flyback converter experiences extremely high voltage spikes $\left(\mathrm{V}_{\mathrm{SW}, \mathrm{C}}\right)$ upto $1250 \mathrm{~V}$ which can damage the MOSFET switch if the switch is not rated to withstand such high voltage. It can be seen that the other flyback converter topologies 


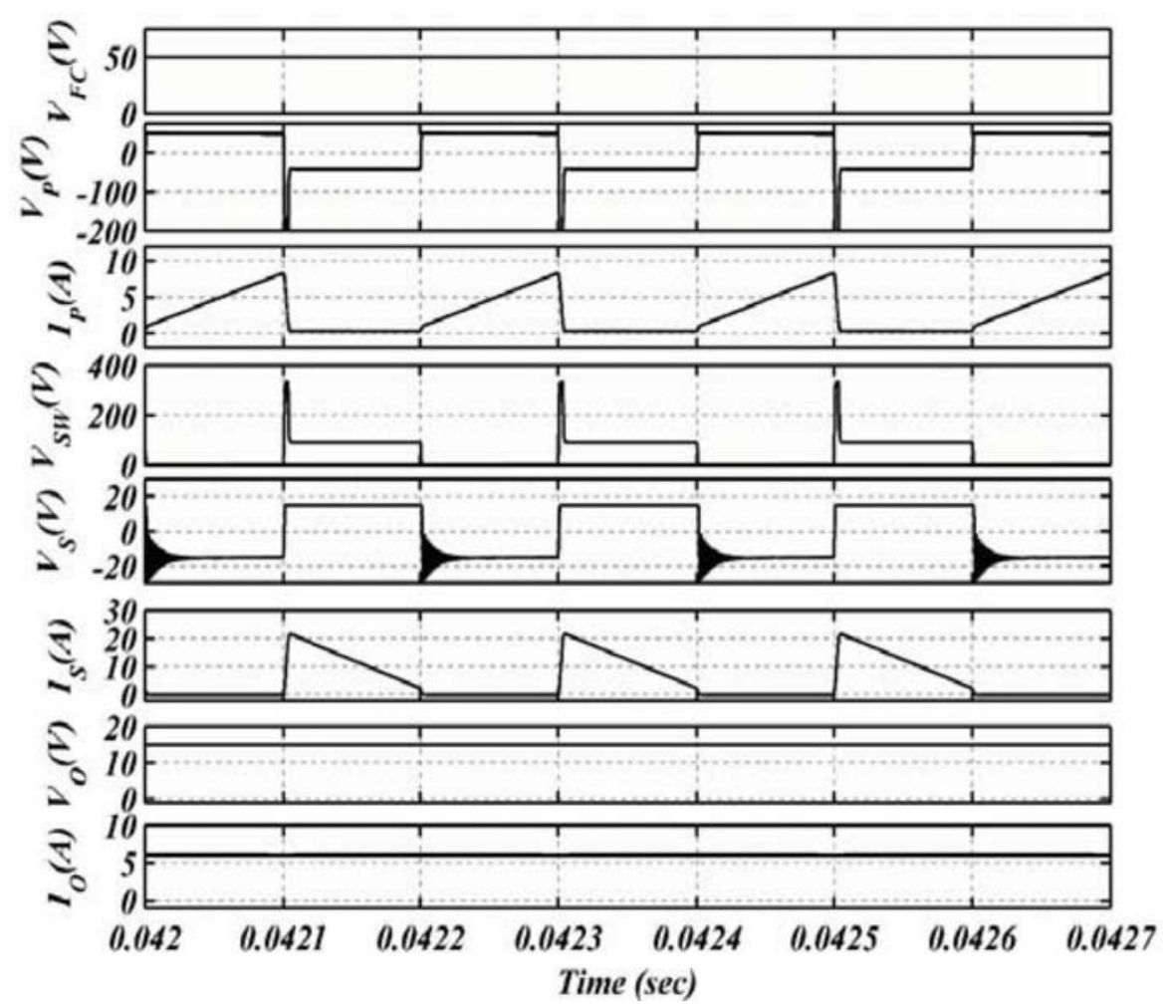

Figure 9 Performance waveforms of RCD flyback converter with fuel cell generated voltage as input voltage with the switching frequency of $5 \mathrm{kHz}$ at $50 \%$ duty cycle and graphs are plotted as follows: fuel cell voltage $\left(\mathrm{v}_{\mathrm{FC}}\right)$, primary voltage $\left(\mathrm{v}_{\mathrm{P}}\right)$, primary current $\left(\mathrm{i}_{\mathrm{P}}\right)$, voltage across switch $\left(\mathrm{v}_{\mathrm{SW}}\right)$, secondary voltage $\left(\mathrm{v}_{\mathrm{S}}\right)$, secondary current $\left(\mathrm{I}_{\mathrm{S}}\right)$ with output voltage $\left(\mathrm{v}_{\mathrm{o}}\right)$ and output current $\left(\mathrm{I}_{\mathrm{O}}\right)$.

exert comparatively low voltage stress on the switch when compared with conventional flyback converter. The voltage stress $\left(v_{\mathrm{SW}}, \mathrm{AC}\right)$ across the switch in active clamped flyback converter is $100 \mathrm{~V}$, Voltage stress $\left(\mathrm{v}_{\mathrm{SW}, \mathrm{RCD}}\right)$ across the switch in RCD flyback converter is $350 \mathrm{~V}$, Voltage stress ( $\mathrm{v}_{\mathrm{SW}, \mathrm{IL}}$ ) across switch in interleaved flyback converter is $700 \mathrm{~V}$ and Voltage stress ( $\left.\mathrm{v}_{\mathrm{SW}}, \mathrm{TS}\right)$ across switch in two switch flyback converter is $50 \mathrm{~V}$ from this, it can be concluded that the two switch topology experiences the lowest voltage stress on its switches and interleaved topology experiences highest voltage stress when compared across the different topologies of flyback converter excluding the conventional flyback converter. 


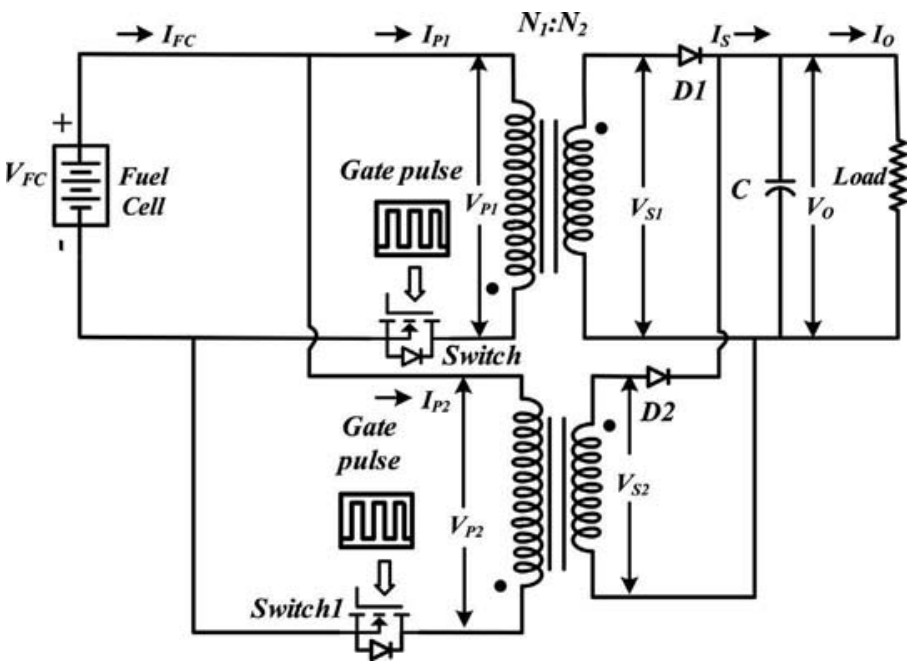

Figure 10 Basic circuit of interleaved flyback Converter.

\section{Flyback Converter Design}

In this paper the flyback converter design issues are discussed. $15 \mathrm{~V} \mathrm{DC}$ output from $50 \mathrm{~V}$ DC supply is chosen for the design providing $90 \mathrm{~W}$ output power. For switching purpose, power MOSFET is used. A diode is used for the rectification purpose. Here design consideration is taken for single winding output with positive and negative terminal. Moreover, for sensor supply consideration is taken such that power is same but at its output two voltages $\pm 15 \mathrm{~V}$ with three terminals that is positive, negative and center tapes are used. Only number of turns in isolated transformer will be twice the number of turns in a single output supply. The specifications of the converter considered for the design are,

Input Voltage, $\mathrm{V}_{\text {in }}=50 \mathrm{~V}$

Output Voltage, $\mathrm{V}_{\mathrm{O}}=15 \mathrm{~V}$

Load current, $\mathrm{I}_{\mathrm{O}}=6 \mathrm{~A}$

Switching Frequency, $\mathrm{F}_{\mathrm{S}}=5 \mathrm{kHz}$

Switching Time Period, $\mathrm{T}_{\mathrm{S}}=1 / \mathrm{F}_{\mathrm{S}}=0.2 \mathrm{msec}$

Converter Efficiency, $\eta=0.85$ or $85 \%$

For more, the flyback converter parameters are given in Appendix-B.

Table 2 shows the efficiency of different flyback converter topology considering the switching frequency of $5 \mathrm{kHz}$. So, lowest efficiency is found in 


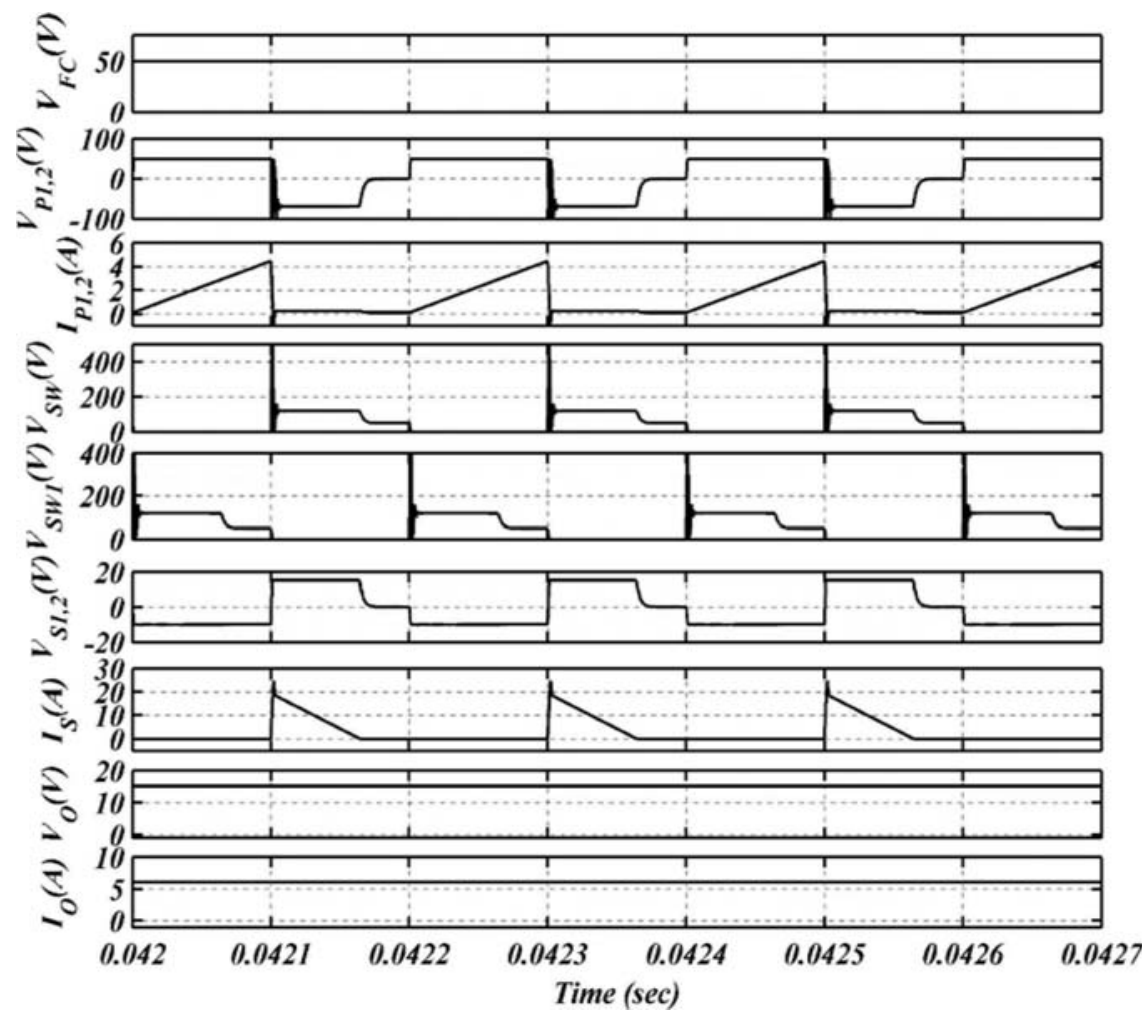

Figure 11 Performance waveform of interleaved flyback converter with fuel cell generated voltage as input voltage with switching frequency of $5 \mathrm{kHz}$ at $50 \%$ duty cycle and graphs are plotted as follows: fuel cell voltage $\left(\mathrm{v}_{\mathrm{FS}}\right)$, primary voltage across both the transformers $\left(\mathrm{v}_{\mathrm{P} 1,2}\right)$, primary current of both the transformers $\left(\mathrm{I}_{\mathrm{P} 1,2}\right)$, voltage across switches $\left(\mathrm{v}_{\mathrm{SW}}\right)$ and $\left(\mathrm{v}_{\mathrm{SW} 1}\right)$, secondary voltage across both the transformers $\left(\mathrm{v}_{\mathrm{S} 1,2}\right)$, secondary current $\left(\mathrm{I}_{\mathrm{S}}\right)$ with output voltage $\left(\mathrm{v}_{\mathrm{o}}\right)$ and output current $\left(\mathrm{I}_{\mathrm{o}}\right)$.

RCD snubber flyback converter with $72.6 \%$ efficiency as per the Table 2. Whereas active clamp flyback topology gives the highest efficiency of $85.2 \%$ which also reduces the high voltage stress on semiconductor devices to a great extent.

Figure 15 shows the output voltage $\left(\mathrm{V}_{\mathrm{o}}\right)$ and current $\left(\mathrm{I}_{\mathrm{o}}\right)$ waveform of flyback converter with the single output of $15 \mathrm{~V}, 6 \mathrm{~A}$. Moreover, when it comes to sensor output keeping power as the same and making two secondary side output for sensor application with two supply with $15 \mathrm{~V}, 3$ A making $90 \mathrm{~W}$ supply as a whole. 


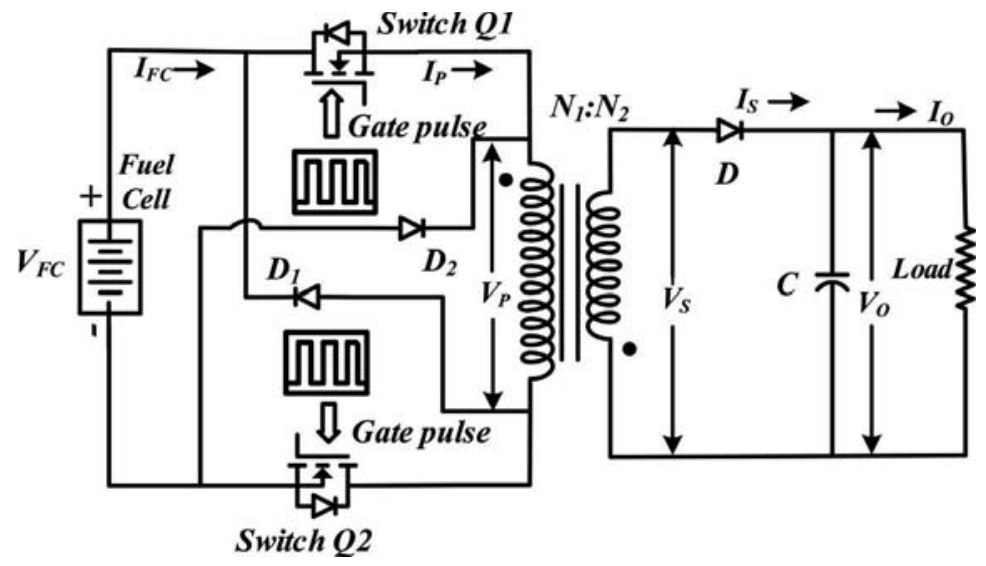

Figure 12 Basic circuit of two switch flyback Converter.

\subsection{Conventional Sensor Supply}

A comparison is made with the conventional sensor supply to appreciate the proposed fuel cell based converter. It is a well-known fact that, in spite of the simplicity the conventional power (linear power) supply suffers severely from efficiency problems. As the focus is on efficiency, the comparison is made with respect to this terms.

\subsubsection{Dual output $+\mathbf{1 5}$ and $\mathbf{- 1 5}$ voltage DC power supply}

A power supply circuit that allows connecting $230 \mathrm{~V} \mathrm{AC}$ input, eventually stepping it down to $\pm 24 \mathrm{~V}$ by a centre tapped transformer can be termed as a linear regulator. This \pm 24 Vac output is connected to two 7815 regulators through a bridge rectifier, for getting regulated voltages in dual $( \pm 15 \mathrm{~V}, \mathrm{DC})$ at its output. This kind of supply is used to power all the op-amp based transducers in industries.

Basic circuit diagram of dual output voltage de power supply is shown in the Figure 16. The diode bridge $\mathrm{D}_{1}-\mathrm{D}_{4}$ ensures the polarity of the output that is independent of the supply voltage polarity. This whole circuit along with the capacitor $\mathrm{C}_{1}-\mathrm{C}_{4}$ converts the $\mathrm{AC}$ input to $\mathrm{DC}$ which is connected to voltage regulators $\mathrm{U}_{1}$ and $\mathrm{U}_{2}$ on the either sides to produce \pm dual voltage output. The 7815 regulator has three legs which convert the varying input voltage to a constant regulated output. Capacitors $\mathrm{C}_{2}, \mathrm{C}_{5}$ and $\mathrm{C}_{3}, \mathrm{C}_{6}$ are connected in parallel between the common leg and the output to achieve the maximum voltage regulation and also ensure the elimination of ripples. 


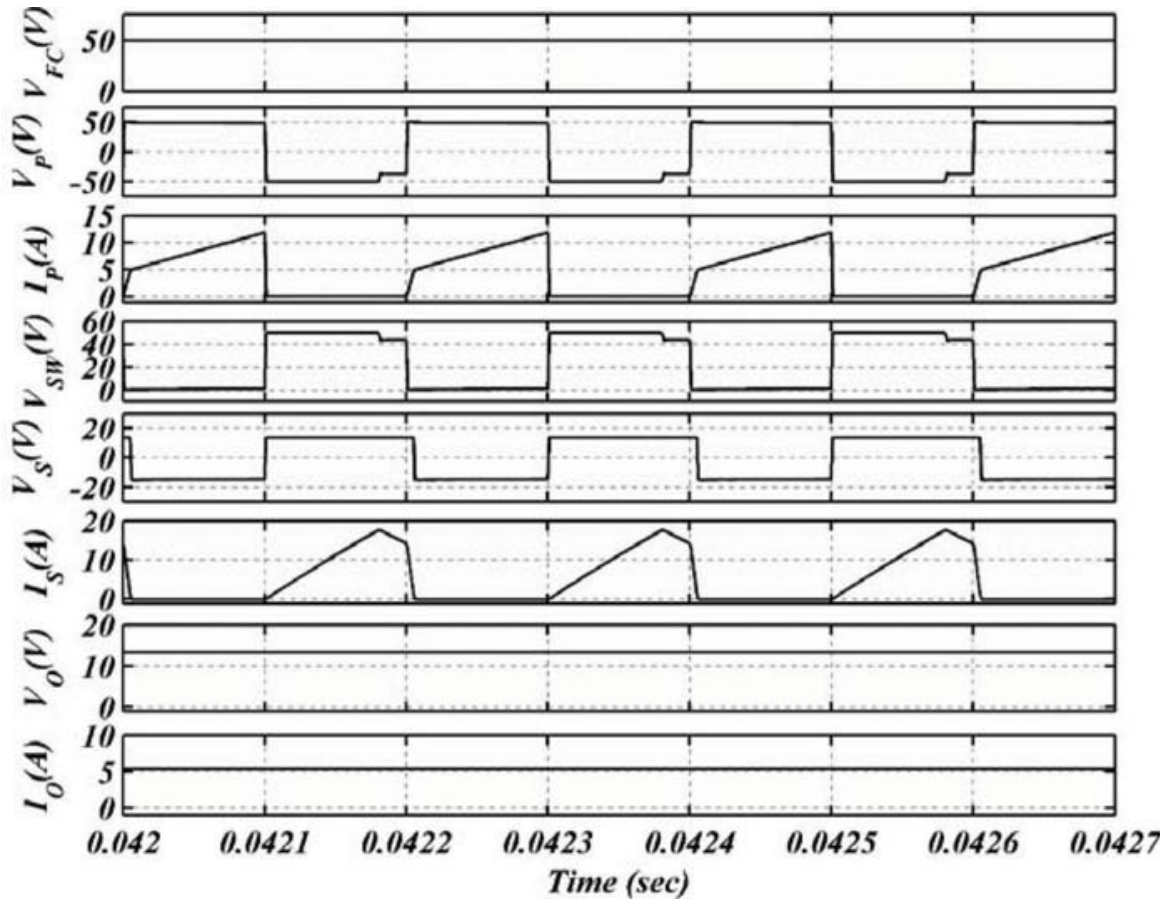

Figure 13 Performance waveforms of two switch flyback converter with fuel cell generated voltage as input voltage with a switching frequency of $5 \mathrm{kHz}$ at $50 \%$ duty cycle and graphs are plotted as follows: fuel cell voltage $\left(\mathrm{v}_{\mathrm{FS}}\right)$, primary voltage $\left(\mathrm{v}_{\mathrm{P}}\right)$, primary current $\left(\mathrm{I}_{\mathrm{P}}\right)$, voltage across both the switches $\mathrm{Q}_{1}$ and $\mathrm{Q}_{2}$ is same i.e $\left(\mathrm{v}_{\mathrm{SW}}\right)$, secondary voltage $\left(\mathrm{v}_{\mathrm{S}}\right)$, secondary current $\left(\mathrm{I}_{\mathrm{S}}\right)$ with output voltage $\left(\mathrm{v}_{\mathrm{o}}\right)$ and output current $\left(\mathrm{I}_{\mathrm{o}}\right)$.

\subsubsection{Comparison between linear regulator and flyback Converter}

Linear regulators like the 7815 are highly inefficient, and are not recommended where the input voltage is higher. It offers a variable resistance to maintain the constant voltage at its output, thus acting as a variable resistor. Hence, the output current consumed by load also flows through the variable resistor. When circuit draws huge power then the power dissipation in the 7815 will be

$$
\mathrm{P}=\Delta \mathrm{V} * \mathrm{I}=(24-15) * 6=54 \mathrm{~W}
$$

The $54 \mathrm{~W}$ loss, in a single component delivering an output power of $90 \mathrm{~W}$, the requirement of heat-sink will be big. This power dissipation will be worst for higher input voltages and the efficiency of regulator can be calculated as, 


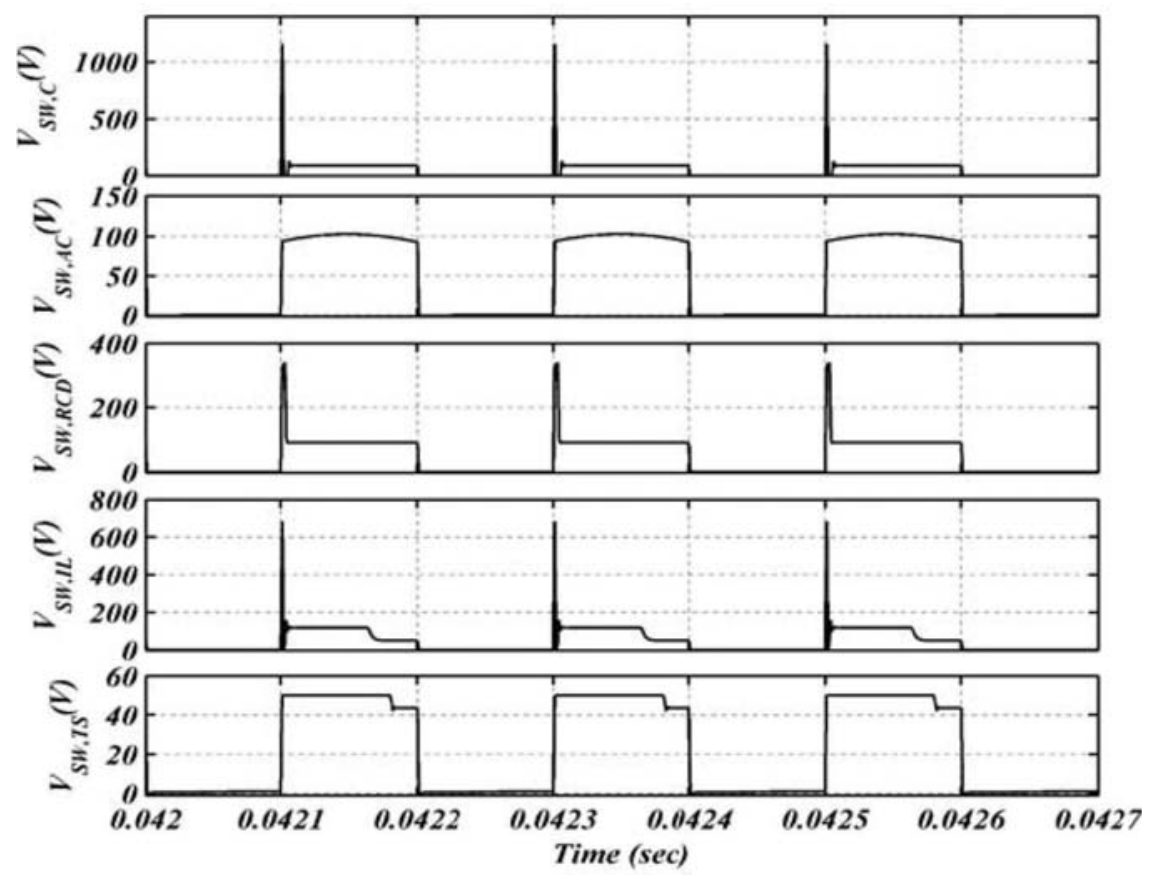

Figure 14 Drain to source voltage stress comparison between conventional flyback converter and its different topologies.

$$
\begin{gathered}
\eta=\mathrm{P}_{\text {out }} / \mathrm{P}_{\text {in }}=\left(\mathrm{V}_{\text {out }} * \mathrm{I}_{\text {out }}\right) /\left(\mathrm{V}_{\text {in }} * \mathrm{I}_{\text {out }}\right)=\mathrm{V}_{\text {out }} / \mathrm{V}_{\text {in }}\left(\text { Since } \mathrm{I}_{\text {out }}=\mathrm{I}_{\text {in }}\right) \\
\text { So } \eta=15 / 24=0.625 \text { or } 62.5 \% \text {. }
\end{gathered}
$$

So with higher input voltages this efficiency will be even poorer and the obvious solution is a switching regulator. Depending on the $\mathrm{V}_{\text {in }} / \mathrm{V}_{\text {out }}$ ratio, there are different types of switching regulators. The actual efficiency can be estimated by the parameters of used components. In a converter having an efficiency of $95 \%$, power dissipated in the regulator can be interpreted as,

$$
\mathrm{P}=((1 / \eta)-1) * \mathrm{P}_{\text {out }}=((1 / 0.95)-1) * 90=4.73 \mathrm{~W}
$$

This is comparatively very low and eliminates the need of a heat sink. The other attractive feature of the switching regulator is the possibility of the entire converter coming in a package with all the other associated components.

Linear regulators are good choice for providing power to low power devices or where the difference in the output and input is very low and provides its advantages of low cost, easy to use and simple construction. 
Table 2 Efficiency comparison between different flyback converter topologies for $5 \mathrm{Khz}$ frequency with $50 \%$ duty cycle

\begin{tabular}{ccc}
\hline S. No. & Flyback Converter Topology & Efficiency \\
\hline 1 & Active clamp & $85.2 \%$ \\
\hline 2 & RCD snubber & $72.6 \%$ \\
\hline 3 & Interleaved & $74.6 \%$ \\
\hline 4 & Two switch & $80.7 \%$
\end{tabular}
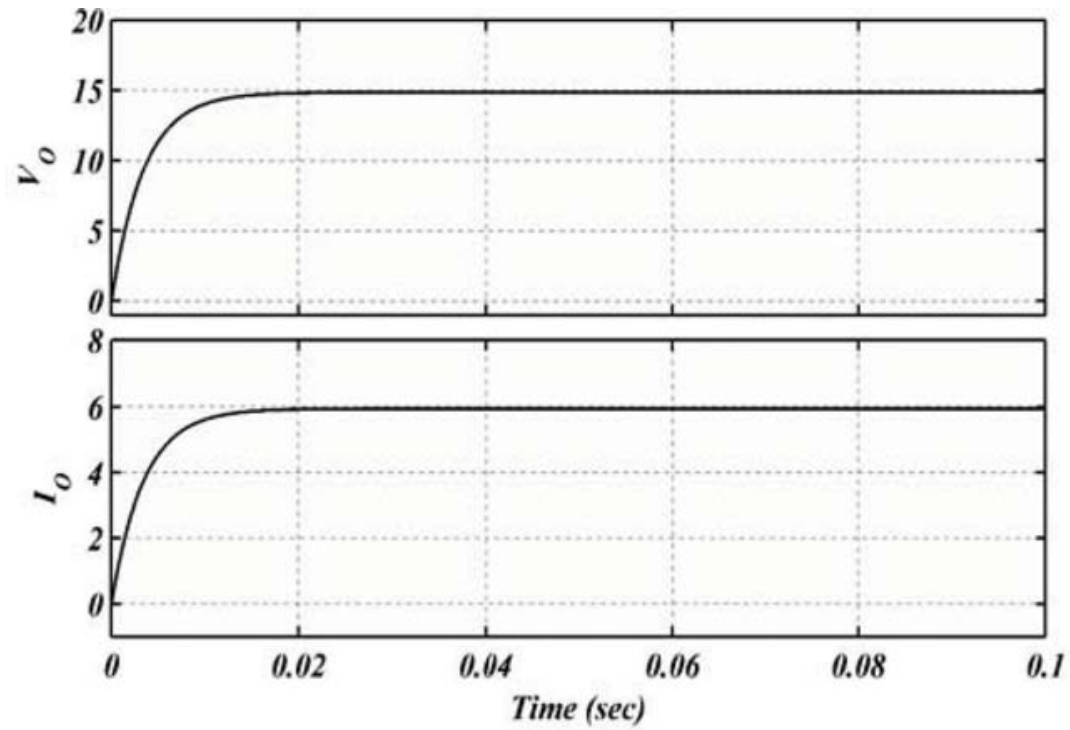

Figure 15 Output voltage and current waveform of flyback converter.

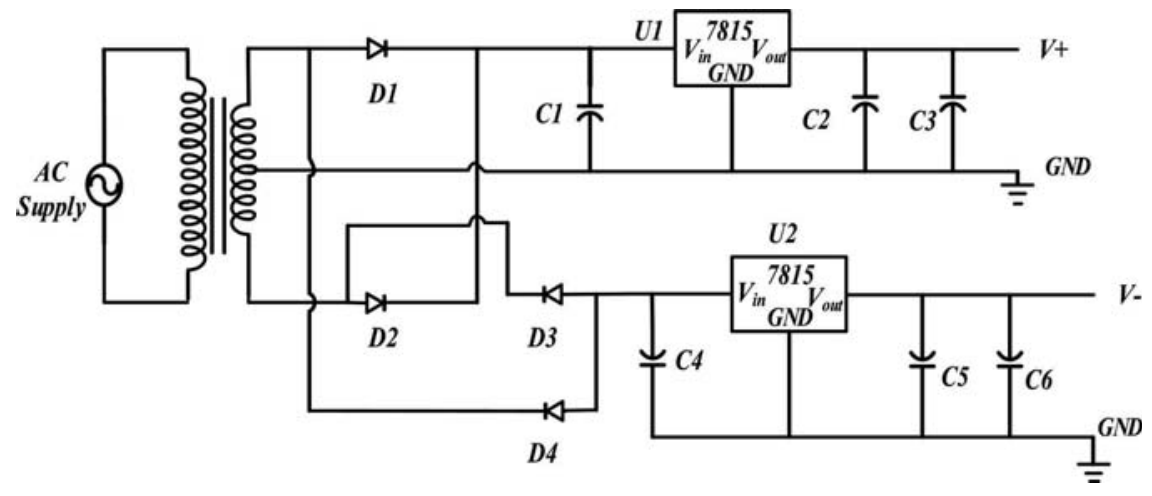

Figure 16 Basic circuit of dual output voltage dc power supply. 
To overcome this disadvantage the switching regulators are the best option which are available in the form of modular compact and reliable chips which further can be divided into non isolated and isolated converters. Some of the advantages of switching regulators are, they can be operated to buck or boost the input voltage unlike in the case of linear regulator where it only bucks the input. The efficiency of switching regulator is high and can be used in medium and high power applications and it can accept the wide range of the input voltage $\left(\mathrm{V}_{\mathrm{in}}\right)$. Thus, flyback converter is opted to power the sensor due to its superiority in almost every aspect. Figure 17 shows the overview of fuel cell output connected to the flyback back converter with its transformer center tapped enabling the flyback converter to produce $\pm 15 \mathrm{~V}$ across its output terminal. This $\pm 15 \mathrm{~V}$ is given to the sensor for its operation. Figure 18 shows the output voltage and current waveform of the center tapped flyback converter with $\mathrm{V}_{\mathrm{o}}^{+}$and $\mathrm{I}_{\mathrm{o}}^{+}$as positive supply as well as $\mathrm{V}_{\mathrm{o}}^{-}$and $\mathrm{I}_{\mathrm{o}}^{-}$as negative supply for the sensor applications.

\section{Experimental Validation}

To validate the simulation study, the proposed system is developed in the laboratory environment. To record the performance of the waveforms, fluke power analyzer (43B) and Agilent make digital oscilloscope are used. The proposed converter is implemented in real time using the Xilinx made Spartan3 FPGA board (XC3S500) with $20 \mu$ s sampling time. An available slot has ADC and signal conditioning blocks with finite number of channels allocated for each block. The parameter variation in input voltage $\left(\mathrm{V}_{\text {in }}\right)$, input current $\left(\mathrm{i}_{\text {in }}\right)$, output voltage $\left(\mathrm{V}_{\mathrm{o}}\right)$, output current $\left(\mathrm{i}_{\mathrm{o}}\right)$, primary voltage $\left(\mathrm{V}_{\mathrm{P}}\right)$, secondary

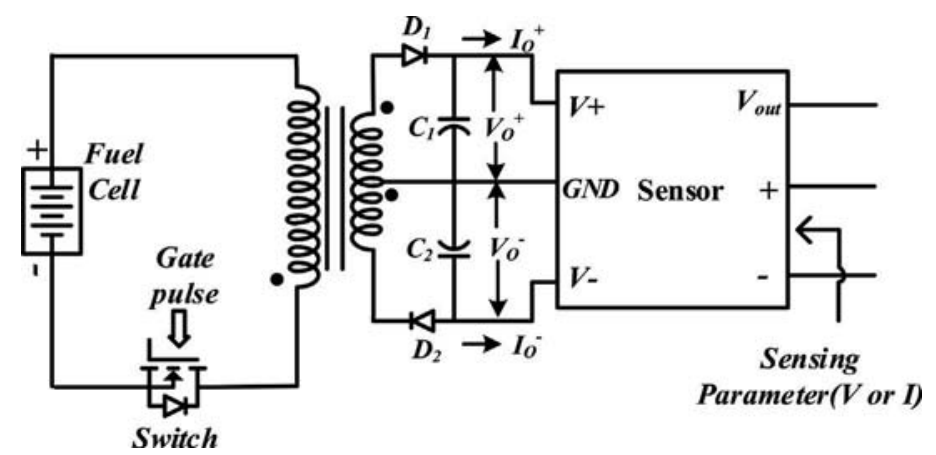

Figure 17 Basic circuit of Fuel cell fed flyback Converter with sensor supply connections. 


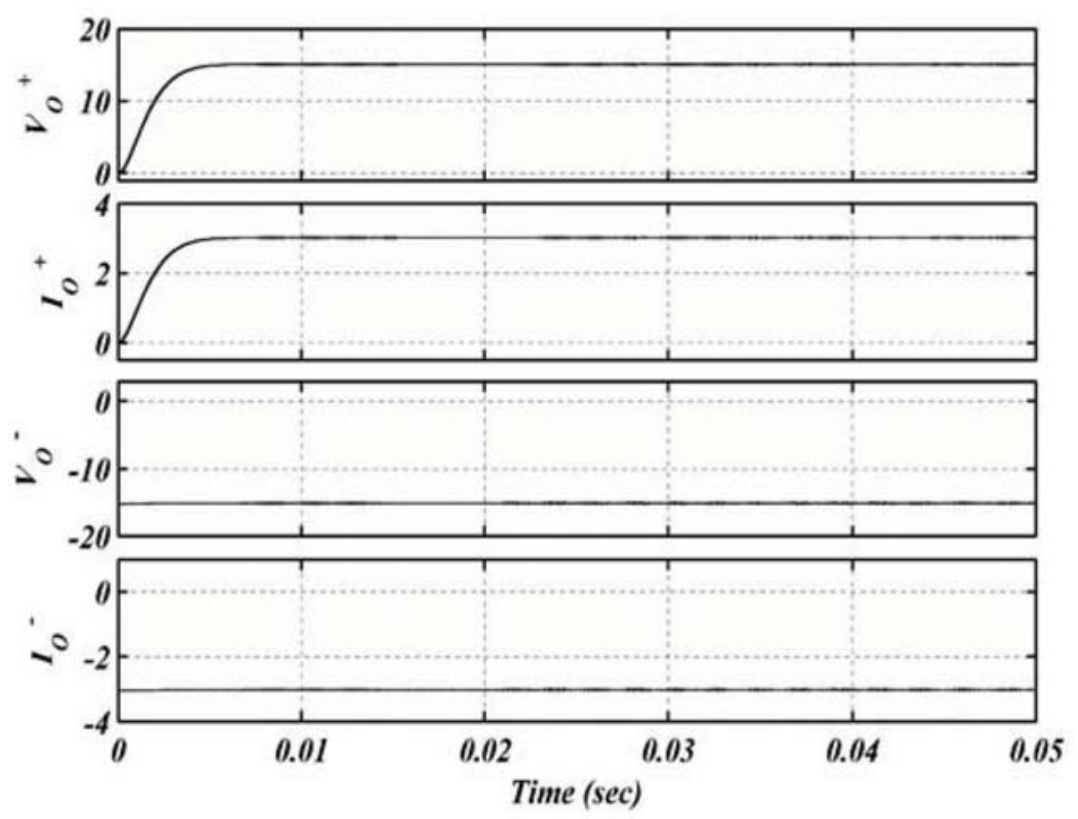

Figure 18 Output voltage and current waveforms of flyback converter in sensor powering application.

voltage $\left(\mathrm{V}_{\mathrm{S}}\right)$, secondary current $\left(\mathrm{i}_{\mathrm{S}}\right)$ and voltage across switch $\left(\mathrm{V}_{\mathrm{SW}}\right)$ are shown the Figure 19-Figure 22. All these performance of the system is validated in basic flyback converter and active clamped flyback converter as discussed below.

\subsection{Performance of Designed Flyback Converter}

Figure 19(a, b) shows the performance waveform of basic flyback converter. The level of input voltage $\left(v_{\text {in }}\right)$, input current $\left(i_{i n}\right)$, output voltage $\left(v_{0}\right)$ and output current are shown in Figure 19(a). Moreover, Figure 19(b) shows waveform of supply current $\left(i_{\mathrm{S}}\right)$, supply voltage $\left(\mathrm{v}_{\mathrm{S}}\right)$, voltage across switches $\left(\mathrm{V}_{\mathrm{sw}}\right)$ and primary side voltage of converter transformer $\left(\mathrm{V}_{\mathrm{p}}\right)$. After observing these waveforms, it can be seen the switch voltage is oscillating due to high switching frequency which is the main problem encountered in basic flyback converter and can be eliminated using active clamp topology. After observing recorded waveform of Input voltage $\left(\mathrm{v}_{\text {in }}\right)$, input current $\left(\mathrm{i}_{\text {in }}\right)$, Input power $\left(\mathrm{P}_{\mathrm{in}}\right)$, Output voltage $\left(\mathrm{v}_{\mathrm{o}}\right)$, output current $\left(\mathrm{i}_{\mathrm{o}}\right)$ and Output power $\left(\mathrm{P}_{\mathrm{o}}\right)$ as shown in Figure 20, the efficiency of basic flyback converter is found to be $90.41 \%$. 


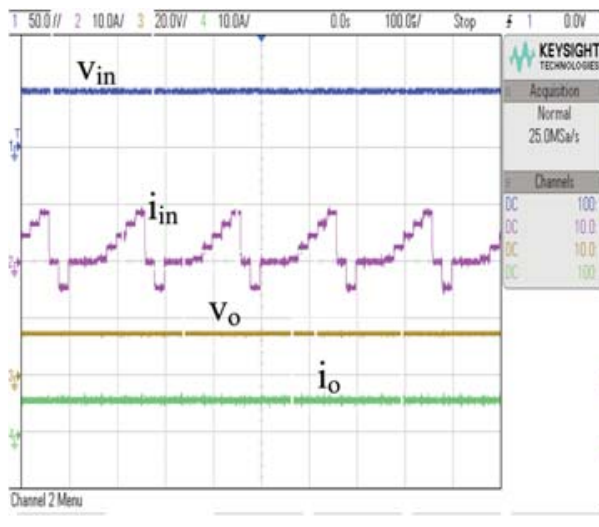

(a)

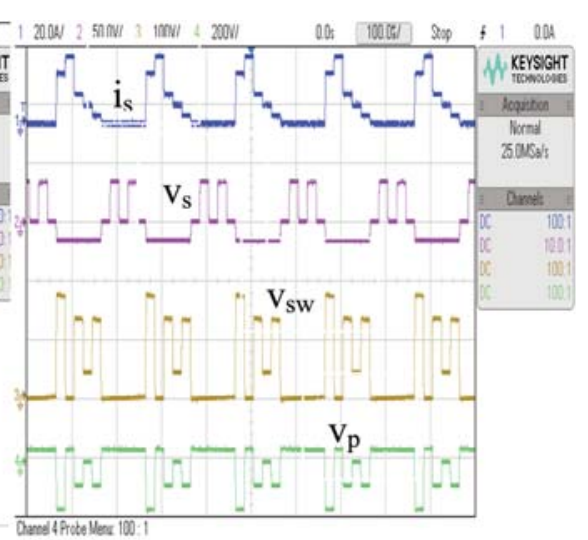

(b)

Figure 19 Steady state performance waveforms of basic flyback converter. (a) Ch. 1 $50 \mathrm{~V} / \mathrm{div}, 2-10 \mathrm{~A} / \mathrm{div}, 3-20 \mathrm{~V} / \mathrm{div}, 4-10 \mathrm{~A} / \mathrm{div}$ and time axis $-100 \mu \mathrm{s} / \mathrm{div}$. (b) Ch. $1-20 \mathrm{~A} / \mathrm{div}$, $2-50 \mathrm{~V} / \mathrm{div}, 3-100 \mathrm{~V} / \mathrm{div}, 4-200 \mathrm{~V} / \mathrm{div}$ and time axis $-100 \mu \mathrm{s} / \mathrm{div}$.

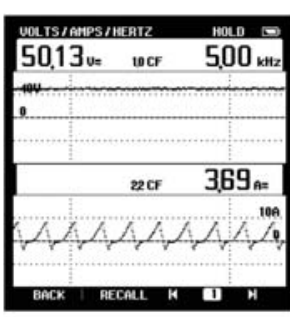

(a)

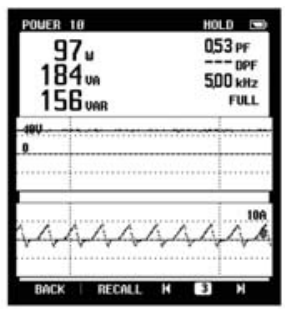

(b)

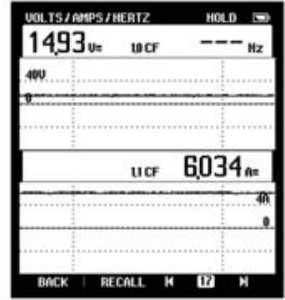

(c)

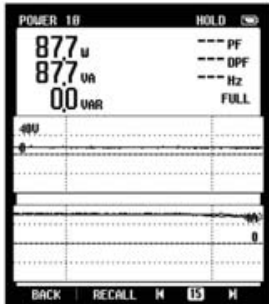

(d)

Figure 20 Steady state waveforms of basic flyback converter (a) Input voltage ( $\left.v_{\text {in }}\right)$ and input current $\left(\mathrm{i}_{\mathrm{in}}\right)(\mathrm{b})$ Input power $\left(\mathrm{P}_{\mathrm{in}}\right)(\mathrm{c})$ Output voltage $\left(\mathrm{v}_{\mathrm{o}}\right)$ and output current $\left(\mathrm{i}_{\mathrm{o}}\right)(\mathrm{d})$ Output power $\left(\mathrm{P}_{\mathrm{o}}\right)$.

\subsection{Performance of Designed Active Clamped Flyback Converter}

Figure 21(a, b) shows the performance waveform of active clamped flyback converter. The level of input voltage $\left(v_{\text {in }}\right)$, input current $\left(i_{\text {in }}\right)$, output voltage $\left(\mathrm{v}_{\mathrm{o}}\right)$ and output current are shown in Figure 21(a). Another side, Figure 19(b) shows waveform of supply current $\left(i_{s}\right)$, supply voltage $\left(v_{s}\right)$, voltage across switches $\left(\mathrm{V}_{\mathrm{sw}}\right)$ and primary side voltage of converter transformer $\left(\mathrm{V}_{\mathrm{p}}\right)$. After observing these waveforms, it can be seen the switch voltage is stable even after having high frequency switching due to the clamp circuit. After observing recoded waveform of Input voltage $\left(v_{i n}\right)$, input 


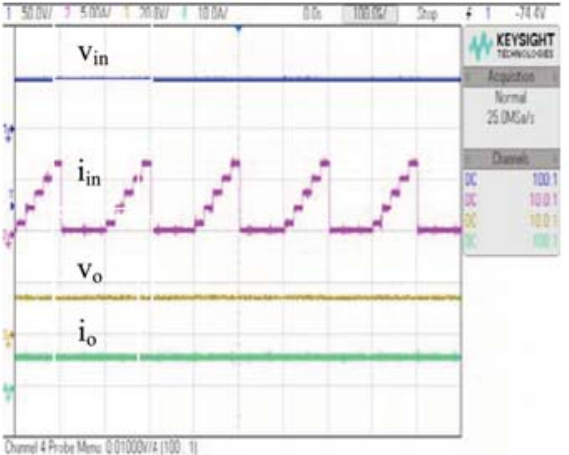

(a)

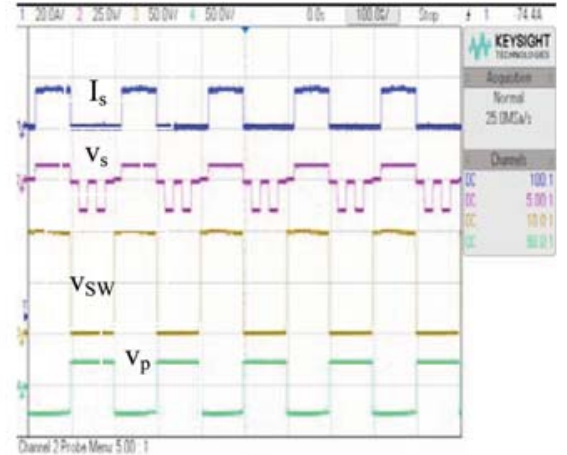

(b)

Figure 21 Steady state performance waveforms of active clamped flyback converter. (a) Ch. $1-50 \mathrm{~V} / \mathrm{div}, 2-5 \mathrm{~A} / \mathrm{div}, 3-20 \mathrm{~V} / \mathrm{div}, 4-10 \mathrm{~A} / \mathrm{div}$ and time axis $-100 \mu \mathrm{s} / \mathrm{div}$. (b) Ch. $1-20 \mathrm{~A} / \operatorname{div}, 2-25 \mathrm{~V} / \mathrm{div}, 3-50 \mathrm{~V} / \mathrm{div}, 4-50 \mathrm{~V} / \mathrm{div}$ and time axis $-100 \mu \mathrm{s} / \mathrm{div}$.

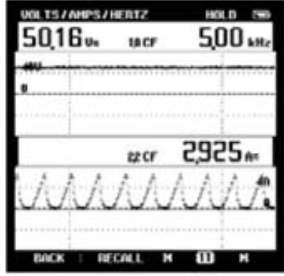

(a)

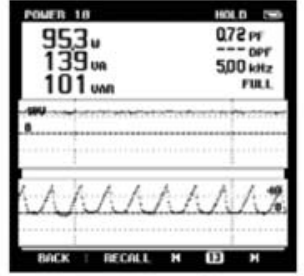

(b)

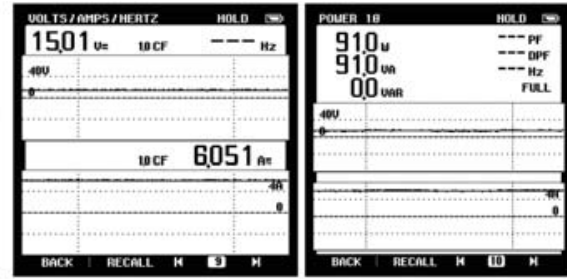

(c)

(d)

Figure 22 Steady state performance waveforms for active clamped flyback converter (a) Input voltage $\left(\mathrm{v}_{\mathrm{in}}\right)$ and input current $\left(\mathrm{i}_{\text {in }}\right)(\mathrm{b})$ Input power $\left(\mathrm{P}_{\mathrm{in}}\right)(\mathrm{c})$ Output voltage $\left(\mathrm{v}_{\mathrm{o}}\right)$ and output current $\left(\mathrm{i}_{\mathrm{o}}\right)(\mathrm{d})$ Output power $\left(\mathrm{P}_{\mathrm{o}}\right)$.

current $\left(\mathrm{i}_{\text {in }}\right)$, Input power $\left(\mathrm{P}_{\text {in }}\right)$, Output voltage $\left(\mathrm{v}_{\mathrm{o}}\right)$, output current $\left(\mathrm{i}_{\mathrm{o}}\right)$ and Output power $\left(\mathrm{P}_{\mathrm{o}}\right)$ as shown in Figure 20. The efficiency of active clamped flyback converter is found to be $95.48 \%$ which is better when compared with conventional flyback converter. So, comparatively active clamp flyback converter gives the better performance and is reliable choice for efficient operation.

\section{Conclusion}

Fuel cells are emerging as more efficient and cleaner source of power generation than conventional sources. Different flyback converter topologies with fuel cells as a power sources are analyzed with their efficiencies and voltage 
stress across the switch as an important parameter. The converter is designed to get $15 \mathrm{~V}$ DC output from $50 \mathrm{~V}$ input DC and the results are compared across the different flyback topologies. Active clamp flyback Converter topology is found to have higher efficiency than others at $5 \mathrm{kHz}$ frequency. The increased efficiency and reduced heat dissipation is observed in the active clamped fuel cell powered flyback converter when compared with the conventional method of supplying power to the sensor. This power supply can be utilized in power sensors like level sensor, angle sensor, anemometer sensor, motion sensor, pressure sensor, temperature sensor, wind vane sensor etc. into on board drive applications. From simulations and experimental validation, it is observed that the voltage stress across the switch is limited to an acceptable value in the active clamped topology offering an efficiency of $95.48 \%$ which is superior in its performance and reliability when compared to the basic flyback converter topology.

\section{Appendix-A}

Fuel Cell Supply Source Details: Temperature $=303 \mathrm{~K}, \mathrm{H}_{2}$ Pressure $=2.5 \mathrm{Atm}$, $\mathrm{O}_{2}=5 \mathrm{Atm}$, Nernst Voltage $=1.25 \mathrm{~V}, 1$ Cell voltage $=1.11 \mathrm{~V}$, Number of cells $=45$, Fuel cell O/P Voltage $=50 \mathrm{~V}$.

Flyback Converter Details: Primary magnetizing inductance, $\mathrm{Lp}=$ $0.5907 \mathrm{H}$, Clamping Diode, $\mathrm{C}_{\text {clamp }}=0.02289 \mathrm{mF}$, Resonant Inductor, $\mathrm{L}_{\mathrm{r}}=$ $0.0443 \mathrm{mH}$, Snubber Capacitor, $\mathrm{C}_{\mathrm{sn}}=0.5077 \mu \mathrm{F}$, Leakage Inductance, $\mathrm{L}_{\mathrm{lk}}=8.86 \mu \mathrm{H}$, Snubber resistance, $\mathrm{R}_{\mathrm{sn}}=5.918 \mathrm{~K} \Omega$, Output capacitor, $\mathrm{C}=4 \mathrm{mF}$.

\section{Appendix-B}

Flyback Converter Parameter Calculations

Load Resistance $(\mathrm{R})=2.5 \Omega$, Forward Voltage of $\operatorname{MOSFET}\left(\mathrm{V}_{\mathrm{T}}\right)=1.2 \mathrm{~V}$, and

Forward Voltage of Diode $\left(\mathrm{V}_{\mathrm{D}}\right)=1 \mathrm{~V}$

Primary side peak current $\left(\mathrm{I}_{\mathrm{PK}}\right)=\left(2 * \mathrm{I}_{\mathrm{in}}\right) / \mathrm{D}$

Primary magnetizing inductance $\left(\mathrm{L}_{\mathrm{P}}\right)=\left(\mathrm{V}_{\text {in }} * \mathrm{D}\right) /\left(\mathrm{f} * \mathrm{I}_{\mathrm{PK}}\right)$

Clamping Diode $\left(\mathrm{C}_{\mathrm{CLAMP}}\right)=(1-\mathrm{D})^{2} /\left(\pi^{2} * \mathrm{~L}_{\mathrm{r}} * \mathrm{f}^{2}\right)$

Resonant Inductor $\left(\mathrm{L}_{\mathrm{R}}\right)=(5-10) \%$ of $\mathrm{L}_{\mathrm{P}}$

Snubber Capacitor $\left(\mathrm{C}_{\mathrm{SN}}\right)=\left(2 * \mathrm{~L}_{\mathrm{LK}} * \mathrm{I}_{\mathrm{PK}}{ }^{2} * \mathrm{n}^{2}\right) / \mathrm{Vo}^{2}$

Leakage Inductance $\left(\mathrm{L}_{\mathrm{LK}}\right)=(1-2) \%$ of $\mathrm{L}_{\mathrm{P}}$

Power dissipation in snubber resistor $\left(\mathrm{P}_{\mathrm{Sn}}\right)=0.833 * \mathrm{~L}_{\mathrm{LK}} * \mathrm{I}_{\mathrm{PK}} 2 * \mathrm{f}$ 
Snubber resistance $\left(\mathrm{R}_{\mathrm{sn}}\right)=\left(6.25 * \mathrm{Vo}^{2}\right) /\left(\mathrm{P}_{\mathrm{sn}} * \mathrm{n}^{2}\right)=5.918 \mathrm{~K} \Omega$

Output capacitor $\left(\mathrm{C}_{\mathrm{o}}\right)=\left(\mathrm{V}_{\mathrm{O}} * \mathrm{D}\right) /\left(\mathrm{f} * \mathrm{R} * \mathrm{AV}_{\mathrm{o}}\right)$

$\Delta \mathrm{Vo}=1 \%$ of ripple in $\mathrm{V}_{\mathrm{o}}$

\section{References}

[1] Sharaf, O. Z., and Orhan, M. F. (2014). Overview of fuel cell technology: fundamentals and applications. J. Renew. Sustainable Energy Rev. 32, 810-853.

[2] Thomas, C. E. (2009). Fuel cell and battery electric vehicles compared. Int. J. Hydrogen Energy 34, 6005-6020.

[3] Larminie, J., and Dicks, A. (2003). Fuel Cell Systems Explained, 2nd Edn. Somerset: John Willey and Sons Ltd.

[4] Chiu, L. Y., Diongand, B., and Gemmen, R. S. (2004). An improved small-signal model of dynamic behavior of PEM fuel cells. IEEE Trans. Ind. Appl. 40, 970-977.

[5] Jee-Hoon, J., Ahmed, S., and Enjeti P. (2011). PEM fuel cell stack model development for real-time simulation applications. IEEE Trans. Ind. Appl. 58, 4217-4231.

[6] Wang, C., and Nehrir, H. (2007). Load transient mitigation for standalone fuel cell power generation systems. IEEE Trans. Energy Convers. 22, 864-872.

[7] Sharaf, O. Z., and Orhan, M. F. (2014). An overview of fuel cell technology: Fundamentals and applications. J. Renew. Sustainable Energy Rev. 32, 810-853.

[8] Mekhilef, S., Saidur, R., and Safari, A. (2012). Comparative study of different fuel cell Technologies. J. Renew. Sustainable Energy Rev. 16, 981-989.

[9] Palma, L., and Enjeti, P. N. (2009). A modular fuel cell, modular DC-DC converter concept for high performance and enhanced reliability. IEEE Trans. Power Electron. 24, 1437-1443.

[10] Kirubakaran, A., Jain, S., and Nema, R. (2009). A review on fuel cell technologies and power electronic interface. J. Renew. Sustainable Energy Rev. 13, 2430-2440.

[11] Boscaino, V., Miceli, R., Capponi, G., and Galluzzo, G. R. (2014). A review of fuel cell based hybrid power supply architectures and algorithms for household appliances. Int. J. Hydrogen Energy 39, 1195-1209. 
[12] Kolli, A., Gaillard, A., De Bernardinis, A., Bethoux, O., Hissel, D., and Khatir, Z. A review on dc/dc converter architectures for power fuel cell applications. J. Energy Convers. Manage. 105, 716-730.

[13] Bauman, J., and Kazerani, M. (2008). A comparative study of fuelcell-battery, fuel-cell ultra capacitor, and fuel-cell-battery-ultra capacitor vehicles. IEEE Trans. Veh. Technol. 57, 760-769.

[14] Ehsani, M., Gao, Y., and Emadi, A. (2009). Modern Electric, Hybrid Electric, and Fuel Cell Vehicles: Fundamentals, Theory, and Design, 2nd Edn. Boca Raton, FL: CRC press.

[15] Suprabha Padiyar, U., and Vedavyasa Kamath, K. (2016). "Design and implementation of a universal input flyback converter," in Proceedings of the International Conference on Electrical, Electronics, and Optimization Techniques (ICEEOT), 3428-3433.

[16] Rashid, M. H. (2001). Power Electronics Handbook. New York: Academic Press.

[17] Vazquez, N., Lopez, H., Hernandez, C., and Calleja, H. (2008). "Multiple output DC-to-DC based on the flyback converter," in Proceedings of the IEEE Power Electronics Congress, 105-108.

[18] Thounthong, P., Davat, B., and Rael, S. (2009). Fuel cell high-power applications. IEEE Ind. Electron. Mag. 3, 32-46.

[19] Mohan, N., Undeland, T. M., and Robbins, W. P. (2007). Power Electronics: Converters, Applications, and Design, Media Enhanced, 3rd Edn. New York: John Wiley and Sons, Inc.

[20] Pressman, A. I., Billings, K., and Morey, T. (2009). Switching Power Supply Design, 3rd Edn. New York: McGraw-Hill.

[21] Hren, A., Korelic, J., and Milanovic, M. (2006). RC-RCD clamp circuit for ringing losses reduction in a flyback converter. IEEE Trans. Circ. Syst. II 53, 369-373.

[22] Patel, H. K. (2008). "Voltage transient spikes suppression in flyback converter using dissipative voltage snubbers," in Proceedings of the IEEE ICIEA, Hefei, 897-901.

[23] Lin, B. R., Chiang, H. K., and Cheng, C. Y. (2008). Soft-switching converter based on biflyback Topology. Electron. Lett. 44, 1272-1274.

[24] Zhang, J., Huang, X., Wu, X., and Qian, Z. (2010). A high efficiency flyback converter with new active clamp technique. IEEE Transaction Power Electron. 25, 1775-1785.

[25] Pressman, A. I., Billings, K., and Morey, T. (2009). Switching Power Supply Design, 3rd Edn. New York: McGraw-Hill Education. 
[26] Rashid, M. H. (2014). Power Electronics: Circuits, Devices and Applications, 3rd Edn. London: Pearson Education.

[27] Hazucha, P., Karnik, T., Bloechel, B., Parsons, C., Finan, D., and Borkar, S. (2005). Area-efficient linear regulator with ultra-fast load regulation," IEEE J. Solid-State Circuits 40, 933-940.

[28] Bizzarri, F., Brambilla, A., and Saggini, S. (2014). Voltage regulators design through advanced mixed-mode circuit simulation. IEEE Trans. Power Electron. 29, 4496-4499.

[29] de Silva, C. W. (2007). Sensor and Actuator: Control System Instrumentation. Boca Raton, FL: CRC Press.

[30] Wilson, J. S. (2005). Sensor Technology Handbook. oxford: Elsevier Inc.

\section{Biographies}

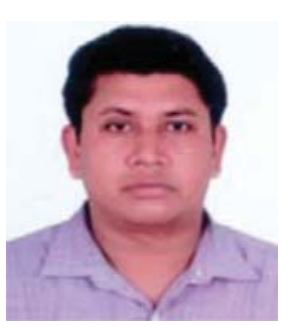

Sabha Raj Arya received Bachelor of Engineering (Electrical Engineering) degree from Government Engineering College Jabalpur, in 2002, Master of Technology (Power Electronics) from Motilal National Institute of Technology, Allahabad, in 2004 and Ph.D. degree from Indian Institute of Technology (I.I.T.) Delhi, New Delhi, India, in 2014. He is joined as Assistant Professor, Department of Electrical Engineering, Sardar Vallabhbhai National Institute of Technology, Surat. His fields of interest include power quality, design of power filters and distributed power generation.

He received Two National Awards namely INAE Young Engineer Award from Indian National Academy of Engineering, POSOCO Power System Award from Power Grid Corporation of India in the year of 2014 for his research work. He has also received Amit Garg Memorial Research Award2014 from I.I.T. Delhi from the high impact publication in a quality journal during the session 2013-2014. He is a Senior Member of the Institute of Electrical and Electronics Engineers (IEEE). 


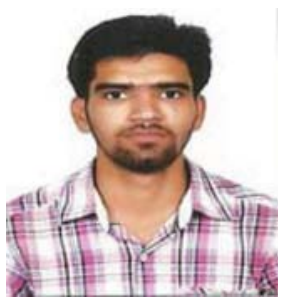

Nunsavath Sharath Kumar received Bachelor of Engineering (Electrical and Electronics Engineering) degree from Jawaharlal Nehru Technological University, Hyderabad in 2014. At present, he is doing his Master degree in Power Electronics and electrical drives from Sardar Vallabhbhai National Institute of Technology, Surat (India). His fields of interest include design of power electronics converters and its application in electrical Engineering.

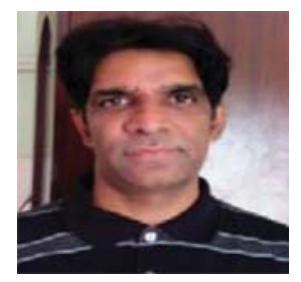

B. R. Ananthapadmanabha received the B.E. degree in electrical engineering from R. V. College of Engineering, Bangalore, India, in 1993, the M.Tech. Degree in electrical engineering with a specialization in power electronics from the B. M. S. College of Engineering, Bangalore, India, in 2005, and is currently pursuing Ph.D. degree in Electrical Engineering at Sardar Vallabhbhai National Institute of Technology, Surat, Gujarat, India. In 2005, he joined Hynetic electronics, Bangalore as field application engineer working in the area of dc/dc converters, battery chargers. In 2011 he joined Incap CMS ltd, Bangalore as Project manager for the product management of UPS, inverters. His fields of interest include power electronics, power quality, and design of $\mathrm{dc} / \mathrm{dc}$ Converters. 
